\title{
Babaların Doğum Eylemine Katılma Konusundaki Görüşleri ve Gereksinimleri
}

\section{The Opinions and Needs of the Fathers on Participating to Labour}

\author{
Zekiye Karaçam ${ }^{1 *}$ Erdal Karatepe ${ }^{2}$ \\ ${ }^{1}$ Aydın Adnan Menderes Üniversitesi, Sağlık Bilimleri Fakültesi, Ebelik Bölümü, Aydın, Türkiye \\ ${ }^{2}$ Özel Tınaztepe Hastanesi, İzmir, Türkiye \\ e-mail: zkaracam@adu.edu.tr, zekiyekaracam@yahoo.com, erdalkaratepe47@gmail.com \\ ORCID: 0000-0002-0419-8961 \\ ORCID: 0000-0001-5874-2216 \\ *Sorumlu yazar/Corresponding author: Zekiye Karaçam ${ }^{1}$
}

Gönderim tarihi/Received:08.03.2020

Kabul tarihi/Accepted:07.05.2020

DOI:10.34087/cbusbed.700561

\section{$\ddot{\mathbf{O} z}$}

Giriş ve Aamaç: $\mathrm{Bu}$ araştırmada, babaların doğum eylemine katılma konusundaki görüş ve gereksinimlerinin belirlemesi amaçlanmıştır.

Gereç ve Yöntemler: Araştırma niteliksel olarak, Şubat 2018'de, Aydın Kadın Doğum ve Çocuk Hastalıkları Hastanesi'nde eşleri vajinal doğum yapmak üzere doğum ünitesine kabulü yapılan ya da yeni bebeği olan 20 baba ile yapılmıştır. Verileri, yapılandırılmış ve yarı yapılandırılmış görüşme formu ile toplanmıştır. Veriler içerik analizi yöntemi ile analiz edilmiş, babaların görüşleri ile ilgili beş ve gereksinimleri ile ilgili de beș tane olmak üzere toplam 10 kod oluşturulmuştur.

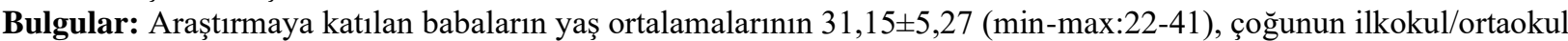
$(n=10)$ ve lise $(n=8)$ eğitiminde oldukları belirlenmiştir. Babaların dördünün ilk, 11'inin ikinci ve üçünün üçüncü kez baba olacakları/oldukları, çoğunun bu gebeliği planladıkları $(n=15)$ ve istedikleri $(n=12)$ belirlenmiştir. Araştırmamızda babaların doğuma katılma ve eşlerine destek olma konusundaki görüşleri "yanında bulunma isteği, destek olma isteği, koruma isteği, fiziksel engeller ve duygusal engeller" kodları altında toplanmıștır. Babaların doğumda katılma ve destek olma ile ilgili gereksinimleri ise "bilgilendirilme, desteklenme, yanında olmaya izin verilmesi, işten izin verilmesi ve ortamın iyileştirilmesi” kodları altında yer almıştır.

Sonuç: Bu çalışmada, babaların doğum eylemine katılma ve eşlerine destek olma konusunda olumlu görüşe sahip oldukları, ancak bunu sağlayabilmek için bilgilendirilme, desteklenme, eşinin yanında olmasına izin verilmesi ve ortamın iyileştirilmesine gereksinim duydukları sonuçları elde edilmiştir. Anne dostu hastane uygulamaları, gebe eğitim sınıfları ve klinik uygulamalar sırasında bu bilgilerin dikkate alınması ile doğumun her iki ebeveyn için de daha keyifli bir deneyime dönüştürülmesine katkı sağlanabilir.

Anahtar kelimeler: Baba, doğuma katılma, ebelik bakımı, görüş, gereksinim, intrapartum bakım,

\footnotetext{
Abstract

Objective: In this study, it was aimed to determine the opinions and needs of the fathers on participating to labour. Materials and Methods: The study was conducted qualitatively in February 2018 at the Aydin Women's Birth and Paediatrics Hospital with 20 fathers who were admitted to the maternity unit to perform vaginal deliveries or with new babies. Data were collected through a structured and semi-structured interview form. The data were analysed by content analysis method and a total of 10 codes were created, five of which were related to fathers' opinions and five related to their needs.

Results: It was determined that the average age of the fathers participating in the study was $31.15 \pm 5.27$ (min-max: $22-41)$, and most of them were in elementary / middle school $(n=10)$ and high school $(n=8)$. Four of the fathers were the first time father, 11 were the second time father, and the third was the third time father / they were going to be fathers, most of whom planned $(n=15)$ and wanted $(n=12)$ to this pregnancies. In this study, the opinions of fathers about participating in birth and supporting their spouses were gathered under the codes of "the desire to stand by, the desire to support, the desire to protect, physical and emotional barriers". The needs of fathers on participation and
} 
support at birth were under the codes of "being informed, supported, being allowed to be with them, being allowed from work and improving the environment".

Conclusion: In this study, it was obtained that fathers had positive opinions about participating in labour and supporting their spouses, but they needed to be informed, supported, and allowed to be with their spouse and to improve the environment. It can contribute to making birth a more enjoyable experience for both parents with taking this information into consideration during mother-friendly hospital practices, pregnant education classes and clinical practices,

Keywords: Birth attendance, father, intrapartum care, midwifery care, need, opinion,

\section{Giriş}

Tüm dünyada babaların gebelik ve doğum sürecine katılmaları, 1960'lardan beri giderek artış göstermiştir [1, 2]. Bu gelişmelere paralel olarak, son yıllarda ülkemizde de babalık rolünde önemli değişiklikler olmuştur [3, 4]. İdeal modern babalık rolü, fiziksel, emosyonel, ekonomik ve sosyal sorumlulukların yanı sıra babanın güçlü bir băg ile çocuğuna bağlanmasını, ebeveyn rollerini anne ile paylaşmasını, perinatal bakım ve çocuğun bakımında daha fazla rol almasını gerektirmektedir $[5,6]$. Ancak yapılan çalışmalar geleneksel babalık rolü ile babaların, çocuklarının bakımında yeterince sorumluluk almadıklarını göstermiştir [3-5]. Bu nedenle modern babalık rolünün önemli bir parçası olarak babaların doğuma katılımı, dikkatle incelenmesi ve üzerinde durulması gereken bir konudur.

İngiltere ve Amerika Birleşik Devletleri'nde babaların \%90'nından daha fazlasının gebelik süresince doğum öncesi bakım hizmetleri sırasında annenin yanında oldukları ve yapılan ultrason gibi işlemlere tanıklık ettikleri bildirilmiştir [7, 8]. Anne, gebelik ve doğum sirasında baba tarafindan desteklendiğinde daha olumlu deneyimlere sahip olmaktadır. Aksine olumsuz doğum deneyimi, kadının gelecekteki üremeye ilişkin kararlarını da olumsuz etkileyebilir [2, 9].

Uluslararası literatürde babaların gebelik, doğum ve doğum sonrası dönemlere ilişkin görüş, deneyim ve gereksinimleri ile ilgili bazı çalışmalara rastlanmaktadır. Bu konuda yapılan bir kalitatif araştırmada, Howarth ve ark. [10] anne ve bebeğin güvenliği, destek rolünün anlaşılması, doğum sırasında ağrı ve kontrolde anne, doğum sonrası bakım ve iletişim temalarını ortaya koymuşlardır. Bir başka nitel çalışmada da babaların deneyimlerinin katılım konusunda olumlu olma, tereddüt yaşama, zayıf duygusal tepkiler, destekleyebilme, zihinsel olarak hazırlıklı olma ve bilgilendirilme ihtiyacı temaları altında toplandığ bildirilmiştir [6]. Babaların prenatal ve antenatal bakıma katılımlarını etkiyen durumlar ile ilgili yapılan bir çalışmada ise babanın annenin bakımına katılımı ile yaş, eğitim ve gelir düzeyleri ve tutumu arasında pozitif ilişkinin olduğu bildirilmiştir [11]. Türkiye'de deneysel olarak yapılan bir çalışmada da babanın desteğinin annenin daha olumlu doğum

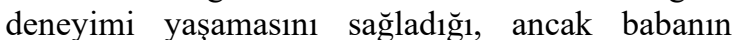
desteği ile doğum eyleminin uzunluğu, analjezik ilaç kullanımı ve obstetrik müdahaleler arasında herhangi bir ilișkinin olmadığı rapor edilmiştir [12]. Babanın doğum eylemine katılma konusundaki davranış ve görüşleri, kültürel ve etnik özelliklerden etkilenebilir $[5,6]$. Ülkemizde yapılan bir araștırmada kadınların \%75'inin doğum eyleminde destek olacak birisine gereksinim duyduğu, destek almayı istedikleri kişileri anne $(\% 44)$, eş (\%31), kardeş $(\% 25)$ ve sağlık personeli (\%10) olarak sıraladıkları ve en çok cesaretlendirmeye (\%42) ihtiyaç duydukları belirtilmiştir [13].

Ebelerin babanın doğum eylemindeki rollerini geliştirme konusunda önemli sorumlukları bulunmaktadır [14, 15]. Ebeler gebelik ve doğum süresinde babaya kültürel olarak uygun ve duyarlı bakım sağlayabilir, babanın ebeveyn rol kalitesinin geliştirilmesine, anne ve bebek için daha olumlu sonuçlar elde edilmesine katkı sağlayabilirler $[1,16]$. Ülkemizde intrapartum bakım hizmetlerinin geliştirilmesi için Anne Dostu Hastane programı uygulamaya konulmuştur. $\mathrm{Bu}$ uygulamanın bir bölümü de doğum eylemi süresince kadının yanında destekleyici bakim verici olarak birinin bulunmasıdır. Bu bakım, birçok gelişmiş ülkede babalar tarafindan yerine getirilmektedir. Babaların perinatal bakıma katılmaları bebeğin gelișimi ve bebeğe bağlanmasını olumlu etkilemektedir [17]. Longworth ve ark. [1] da babaların intrapartum bakıma katılmaları konusunda, sağlık çalışanlarının çalışmalarını kolaylaştırabilecek daha fazla bilimsel bilgiye gereksinim olduğunu bildirmişlerdir. Ayrıca ülkemizde bu konuda yapılan herhangi bir çalışmaya rastlanmıştır. $\mathrm{Bu}$ nedenle babaların intrapartum bakıma katılımları, ulusal bakımdan da önemli, daha fazla araştırılması ve geliştirilmesi gereken bir konudur. Bu çalışmada babaların doğum eylemine katılma konusundaki görüşleri ve gereksinimlerinin, kültürel özelliklerimizi de yansıtacak biçimde, belirlenmesi hedeflenmiştir. Elde edilen bilgiler, babaların intrapartum bakımda yer almalarının geliştirilmesine ve ulusal bilgi birikimine katkı sağlayabilir.

1.1. Araştırmanın amacı ve araştırma soruları Araştırmanın amacı, babaların doğum eylemine katılma konusundaki görüş ve gereksinimlerini belirlemektir. Araştırmada yanıtlanması hedeflenen sorular şunlardır:

1. Babaların doğum eylemine katılma konusundaki görüşleri nelerdir?

2. Babaların doğum eylemine katılma konusundaki gereksinimleri nelerdir? 


\section{Materyal ve Metot}

\subsection{Araştırmanın türü ve örneklemi}

Araştırma niteliksel olarak, Şubat- Aralık 2018 tarihleri arasında, Aydın Kadın, Doğum ve Çocuk Hastalıkları Hastanesi'nde yapılmıştır. Çalışmada nitel araştırma yaklaşımlarından bireylerin algıları, hisseleri ve deneyimlerini konu alan fenomenolojik yaklaşımdan [18] yararlanılarak, babaların doğum eylemine katılma konusundaki görüş ve gereksinimleri açıklanmaya çalışılmıştır.

Araştırmanın yürütüldüğü hastanenin verilerine göre 2017 y1lında 4623 doğum olduğu ve bunların 2977'sinin vajinal yol ile gerçekleştiği rapor edilmiştir [19]. $\mathrm{Bu}$ araştırmada, en az alınması gereken örneklem hacmi, nitel araştırmalarda örneklem hacminin, araştırma sorularına verilen yanıtların doygunluk noktasına ulaşmasına (tekrarlamasına) göre belirlenebileceği ve genellikle 5-25 kişinin yeterli olduğu [18, 20] bilgisine dayalı olarak belirlenmiştir. Araştırmaya eşleri doğum yapmak üzere doğum ünitesine kabulü yapılan ya da yeni bebeği olan babalardan amaçli örnekleme yöntemi ile belirlenen 20 baba dahil edilmiştir. Araştırmanın dâhil edilme kriterlerini eşleri vajinal doğum yapmak üzere doğum ünitesine yatışının yapılması, düşük riskli doğum eylemi beklenmesi ve babada herhangi bir fiziksel ya da ruhsal sağlık probleminin bulunmaması oluşturmuştur. Eşleri acil sezaryen ile doğum yapan ve yine anne ya da bebekte herhangi bir komplikasyon gelişen babalar çalışma kapsamı dışında bırakılmıştır.

2.2. Veri toplama araçlart ve verilerin toplanması Araştırma verileri, araştırmacılar tarafindan konu ile ilgili litaratüre dayalı olarak hazırlanan yapılandırılmış ve yarı yapılandırılmış anket formu ile toplanmıştır $[10,13,17]$. Soru formunda baba ve eşinin bazı özelliklerini sorgulayan 20 yapılandırılmış soru, deneyimlerini ve gereksinimlerini sorgulayan yarı yapılandırılmış 4 soru yer almaktadır. Görüşme formunun kapsam geçerliğini sağlamak için nitel araştırma konusunda deneyimli üç uzmanın görüşleri alınmış ve yapılan öneriler doğrultusunda yeniden düzenleme yapılmıştır. Daha sonra bu formun anlaşılabilirliği ve uygulanabilirliğini geliştirmek ve görüşmenin standardizasyonunu sağlamak için beş baba ile ön uygulama yapılmış ve soru formuna son şekli verilmiştir. Ön uygulamada elde edilen veriler analize alınmamıştır.

Verilerin toplanmasında öncelikle babalar ile tanışılmış ve onlara araştırma hakkında bilgi verilmiş ve yazılı onamları alınmıştır. Ardından yüz yüze görüşme yapılarak anket formunun baba ve eşinin bazı özelliklerini sorgulayan soru bölümü doldurulmuştur. Araştırmanın nitel verileri hazırlanan açık uçlu sorular ile yarı yapılandırılmış görüşme yapılarak elde edilmiştir. Görüşmede babalara açık uçlu sorular yöneltilmiş ve cevapları araştırmacı tarafından görüşme formuna kayıt edilmiştir. Kurum izni sırasında ses kaydı alınması uygun görülmediğinden, verilerin güvenirliğini sağlamak amacı ile görüşme tamamlandıktan sonra yapılan kayıtlar, kișilere okunarak eklemek ya da çıkarmak istedikleri olup olmadığı sorulmuş ve istenilen duruma göre kayıtlarda yeniden düzenleme yapılmıştır. Görüşmeler yaklaşık 15-20 dakikada tamamlanmıștır.

Araştırma verileri, niteliksel araştırma deneyimi olan ikinci araştırmacının süpervizörlüğünde, ebelikte lisans eğitiminin üçüncü yılında olan birinci araştırmacı tarafından toplanmıştır. Bu araştırmacı doğum ve intrapartum derslerini başarı ile tamamlayan bir erkek ebe öğrenci idi. Bu durum babalar ile görüşmede kolaylık oluşturdu. Ön uygulama her iki araştırmacı tarafindan birlikte yapılmış ve bu sırada görüşmenin nasıl yapılacağ1 konusunda birinci araştırmacı gösterilerek ve yaptırılarak eğitilmiştir. Görüşme sırasında babaların mahremiyetleri dikkate alınmış, görüşmeler hastane içerisinde uygun ve boş olan bir odada, uygun oldukları bir zamanda yapılmıştır.

\subsection{Araştırmanın etik boyutu}

Araştırma protokolü Aydın Adnan Menderes Üniversitesi Sağlık Bilimleri Fakültesi Girişimsel Olmayan Klinik Araştırmalar Etik Kurulu tarafından onaylanmıştır (Protokol No: 2017/57). Araştırma verilerinin toplanabilmesi için Aydın İli Kamu Hastaneler Birliği Genel Sekreterliğinden izin alınmıştır (Tarih: 26.01.2018 ve Say1: 69836136/605.01). Araştırmaya dâhil edilen babalara araştırma ile ilgili bilgi verilmiş, çalışmaya katılmaya davet edilmiş, sözlü ve yazılı onamları alınmıştır.

\subsection{Verilerin analizi}

Babalar ve eşlerine işlerine ilişkin tanıtıcı ve obstetrik özellikler ile doğum öncesi bakım hakkındaki verileri sayı ile değerlendirilmiştir. Araştırmanın nitel verilerinin analizinde içerik analizi yöntemi kullanılmıştır. Babaların doğum eylemine katılma konusundaki görüş ve gereksinimleri ile ilgili sorulara verdikleri yanıtlar hiçbir değişiklik yapılmadan olduğu gibi Microsoft Word belgesine aktarılmıştır. Bu kapsamda Times New Roman, 12 punto, satır aralığ 1,5 özelliklerinde 5 sayfa ham veri elde edilmiştir. $\mathrm{Bu}$ veriler tümevarım içerik analizi ve betimsel analiz yoluyla çözümlenmiştir. Babaların sorulara verdiği yanıtlar satır satır okunarak başlangıç kodlar oluşturulmuştur. Ardından ortak yönleri olan başlangıç kodları alt tema ve temalarda birleştirilmiştir. Veriler, örnekleri ile birlikte oluşan tema çeşitliliği ve yoğunluğu yorumlanarak sunulmuştur. Nitel verilerin analizi birinci araştırmacı tarafından yapılmıştır. Araştırmada iç güvenirliği sağlamak amacıyla, beş babadan elde edilen nitel veriler ile bu araştırmada rolü olmayan bir başka araştırmacının başlangıç kodlarını belirlemedeki uyumu incelenmiş ve bu uyumun $\% 83$ olduğu belirlenmiştir. Güvenirlik hesaplamasında 
uyuşum oranın $\% 80$ olması yeterli kabul edilmektedir [21].

arasında değişmekte idi. Babalar eşlerinin gebelik sayısının 1-8 (median: $2 \pm 1.77$ ) ve yaşayan çocuk

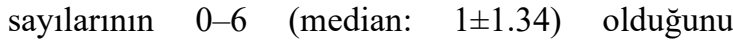
bildirmişlerdir. Babalar ve eşleri ile ilgili diğer bazı tanıtıcı veriler Tablo 1'de verilmiştir.

Tablo 1. Babalar ve eşlerinin tanıtıcı verileri $(n=20)$

\begin{tabular}{|c|c|}
\hline Veriler & Sayı \\
\hline \multicolumn{2}{|l|}{ Eğitimi } \\
\hline İlkokul / ortaokul & 10 \\
\hline Lise & 8 \\
\hline Lisans / lisansüstü & 2 \\
\hline \multicolumn{2}{|l|}{ Eşin eğitim durumu } \\
\hline İlkokul / ortaokul & 15 \\
\hline Lise & 2 \\
\hline Lisans & 3 \\
\hline İșsiz olma & 4 \\
\hline Sağlık güvencesi olma & 20 \\
\hline \multicolumn{2}{|l|}{ Algllanan gelir düzeyi } \\
\hline Gelir, giderden az & 8 \\
\hline Gelir, giderden denk & 9 \\
\hline Değişken & 3 \\
\hline $\begin{array}{l}\text { Yaşadığı yer } \\
\text { İl Merkezi } \\
\text { İlçe Merkezi }\end{array}$ & $\begin{array}{l}7 \\
13\end{array}$ \\
\hline En son gebeliğin planlanmamış olması & 5 \\
\hline En son gebeliğin istenmemesi & 2 \\
\hline \multicolumn{2}{|l|}{ Doğum öncesi bakım alınan yerler } \\
\hline ASM & 3 \\
\hline ASM / Kadın doğum hastanesi & 9 \\
\hline ASM / Kadın doğum hastanesi / özel hastane & 7 \\
\hline ASM / Kadın doğum hastanesi / üniversite hastanesi & 1 \\
\hline Takipler sırasında eşin yanında bulunma & 17 \\
\hline \multicolumn{2}{|l|}{ Takipler sırasında eșin yanında bulunma ile ilgili görüșler } \\
\hline Bulunmadım & 3 \\
\hline Dışardaydım, ben içeri girmedim / alınmadım & 6 \\
\hline Acı deneyimler yaşadım yanlış teşhis koyuldu eşime & 3 \\
\hline Stresli bir süreçti / sıkıntılıydı & 1 \\
\hline Daha fazla sorumluluk aldım & 2 \\
\hline Bu konuda daha çok bilgi sahibi olmayı isterdim & 1 \\
\hline Eşimin yanında olma ve destek olma çok güzel bir duyguydu & 4 \\
\hline Eşin gebe bilgilendirme sınıflarına katılması & 4 \\
\hline Eş ile birlikte gebe bilgilendirme sınıflarına katılma & 0 \\
\hline
\end{tabular}

\section{Bulgular}

Araştırmaya katılan babaların yaşları 22-41 (median: $30 \pm 5.27$ ) ve eşlerininki 18-37 (median: $27 \pm 5.32$ )

Araştırmamızda babaların doğuma katılma ve eşlerine destek olma konusundaki görüşleri "yanında bulunma isteğ $i$, destek olma isteği, koruma isteği, fiziksel engeller ve duygusal engeller" kodlar altında toplanmıştır (Tablo 2). Babaların doğum eylemine katılma konusundaki görüşleri ile ilgili bazı ifadeleri şöyledir;

“......Eşimin yanında bulunmak isterdim, çok isterdim elini tutmak isterdim. Ama burada şu kapıyı aşamıyorsunuz. ..... tabi anında bilgi almamak sikıcı (B1).

"Tabi ki de destek olurum o benim eşim birlikte bu kadar zaman geçirdikten sonra onu böyle bir durumda yalnız bırakmam kötü hissettiriyor" (B20). "Orada bulunmak isterim tabi ki eşim benden destek alır" (B5).

"Belki ben orada olsam eşime daha iyi davranırlar. Kötü mü davranıyorlar iyi mi davranıyorlar bilemem ama ben orada olsam buna izin vermem tabi ki" (B5).

"Hastaneye geldiğinizde içerdeki yatan hastaların mahremiyeti açısından erkek refakatçı almadıkları için dışarda bekletilmek zorunda kallyoruz, ancak her odanın farklı olmasına rağmen yine aynı şekilde hastaların eşlerini almıyorlar yani sıkıntımız bu" (B7).

"Destek olurdum ama o acıya dayanamam. O yüzden doğum salonunda yapamam” (B8).

"Kararsızım eşimin yanında bulunmak isterim ama korkutucu bir ortam" (B11).

Araştırmaya katılan babaların doğumda katılma ve destek olma ile ilgili gereksinimleri "bilgilendirilme, desteklenme, yaninda olmaya izin verilmesi, işten izin verilmesi ve ortamın iyileştirilmesi" kodları altında toplanmıştır (Tablo 3).

Bazı babalar eşlerinin yanında olabilme ile ilgili gereksinimlerini şöyle dile getirmişlerdir:

"Çektiği acının nasıl bir acı olduğunu bilmek isterdim onu nasl rahatlatabilirdim bilmek isterdim. ...." (B1). 
Tablo 2. Babaların doğum eylemine katılma ve eşlerine destek olma konusundaki görüşleri

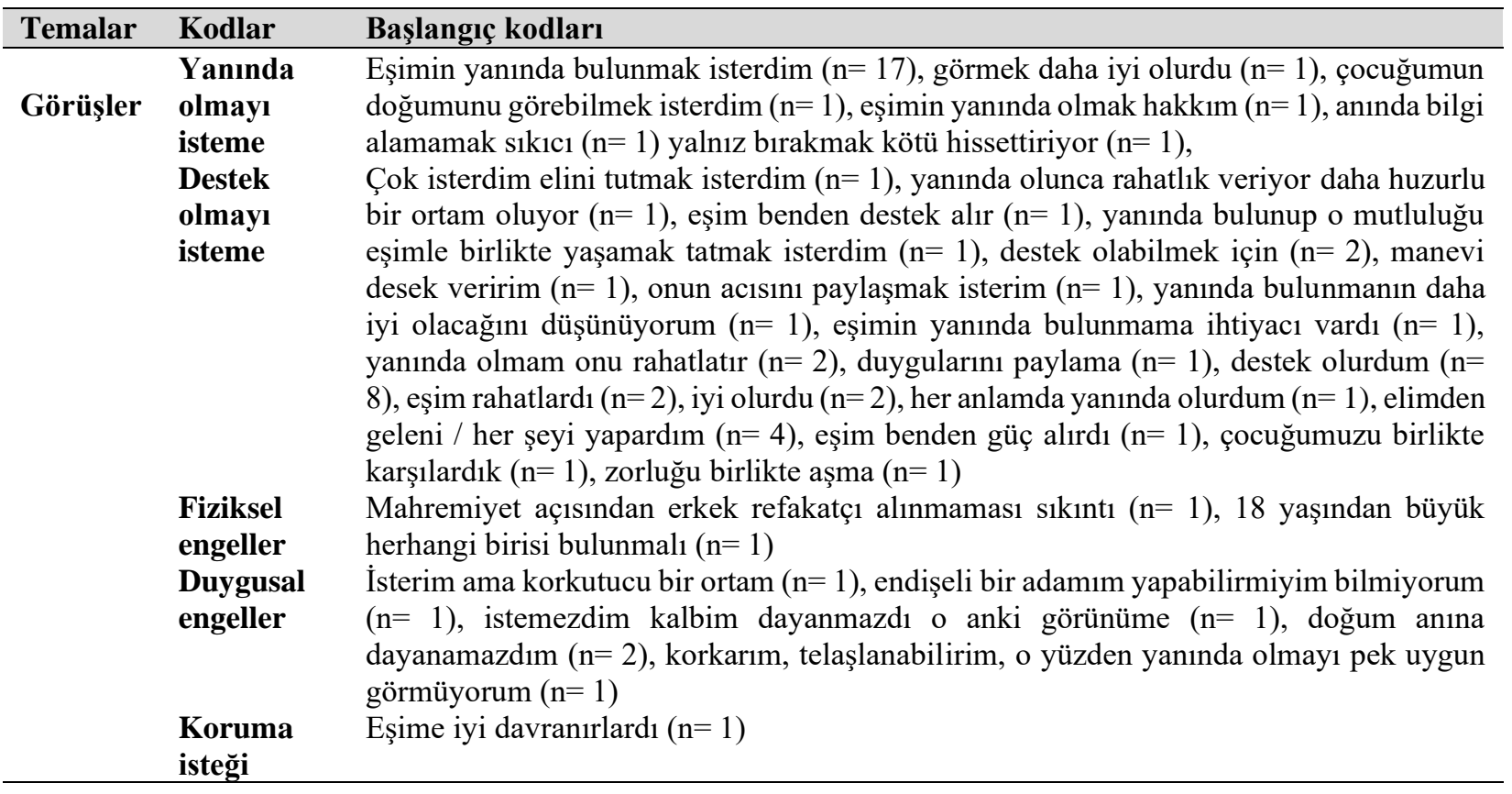

"Eşimizin yanında olmamı izin verilsin yeter onların yanında olmak en büyük hakkımız” (B15).

"Cesarete ihtiyacım var ĕger orda bilgi verilirse bende eşimde daha rahat olur" (B19).

"Hastanelerin destekleri önemli yani hastanelerde ki destekte ebelerin ailelere karşı yaklaşımları doktorların insani yaklaşımları önemli............ Yani is yeriniz size bir günlük izin verebilir siz, rapor alıp devam edebilirsiniz, ancak iş yerinizde sıkıntı olabilir. .........." (B7).

"Ortama adapte olmaya” (2).
"Bilgilendirme daha net bir şekilde yapılsa daha iyi olabilir aslında olasılık olarak bırakılmaması gerekir" (B4).

"Iyi bir muamele iyi bir çevre yardımı. Moral verilmesi" (B8).

"Dediğim gibi korkutucu bir ortam daha iyi hale getirilirse belki girebilirim” (B11).

"Hastane yönetimi ve doktorların biraz daha insani yaklaşması konusunda destek konusunda daha insani yaklaşmaları daha iyi olabilir" (B12).

"Sadece yanında olmak, başka bir şeye ihtiyacım olmaz bence orada" (B20).

Tablo 3. Babaların doğum eylemine katılma ve eşlerine destek olma konusundaki gereksinimleri $(n=20)$

\begin{tabular}{|c|c|c|}
\hline Temalar & Kodlar & Başlangıç kodları \\
\hline \multirow{6}{*}{ 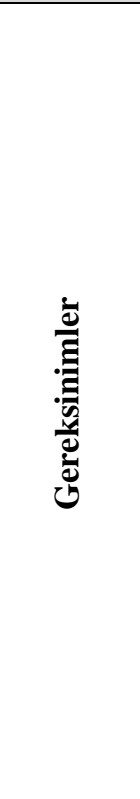 } & Bilgilendirilme & $\begin{array}{l}\text { Eşimi nasıl rahatlatabileceğimi bilmek istedim }(n=1) \text {, ortamı görme /adapte } \\
\text { olmaya }(n=1) \text {, bilgilendirme }(n=4) \text {, ne yapabileceğimin ögretilmesine }(n=2) \text {, } \\
\text { çektiği acının nasıl bir acı olduğunu bilmek isterdim }(n=1) \text {, elimizden gelen } \\
\text { seyleri yapmaya calıșırız bilgi versinler }(n=1) \text {, bilgiler verilsin }(n=1)\end{array}$ \\
\hline & Desteklenme & $\begin{array}{l}\text { Morale }(n=1) \text {, cesarete }(n=1) \text {, sağlık çalışanlarının desteğine }(n=2) \text {, biraz daha } \\
\text { esnek davranmasına }(n=1) \text {, ebe ve diğer çalışanların bu konuda eşlere destek } \\
\text { olması }(n=1) \text {, hastane yönetimi ve doktorların biraz daha insani yaklaşmaları }(n=\end{array}$ \\
\hline & & 1) Ortama adapte olmaya $(n=1)$, yardım edilmesi uygun olur $(n=1)$, \\
\hline & $\begin{array}{l}\text { Yanında } \\
\text { olmaya izin } \\
\text { verilmesi }\end{array}$ & $\begin{array}{l}\text { Doğumhanede bulunmak isterim }(n=4) \text { içeri gidemiyoruz yanında olamıyoruz } \\
(n=1) \text {, yanında olmamız izin verilsin yeter }(n=3) \text {, yanında içeriye alınsam yeter } \\
(n=2) \text {, yanında bulunamadım }(n=1) \text {, uzakta elini bile tutsam bu benim için çok } \\
\text { güzel bir duygu olur }(n=1) \text {, çocuğumu doğum anında gördüğ̈̈mde kendi } \\
\text { kucağıma almak isterim }(n=1) \text {, o anı ölümsüzleştirmek isterdim }(n=1) \text {, sadece } \\
\text { orada olsam da yeterliydi }(n=3) \text {, eşimin elini tutsam yeter bana }(n=1)\end{array}$ \\
\hline & $\begin{array}{l}\text { Ortamın } \\
\text { iyileştirilmesi }\end{array}$ & $\begin{array}{l}\text { Ortamın görünüşüne }(n=1) \text {, ortamin iyileştirilmesine }(n=3) \text {, eşime gereken neler } \\
\text { varsa ona ihtiyaç olur }(n=1) \text {, tek kişilik oda olması lazım }(n=1) \text {, gerekli her şeyi } \\
\text { yapıllyor zaten }(n=1) \text {, uygun ortam hazırlansa tek kişilik odalar olsa }(n=2) \text {, } \\
\text { uygun ortam sağlansın }(n=2) \text {, uygun ortam olsun eşime destek olurum }(n=1)\end{array}$ \\
\hline & $\begin{array}{l}\text { İşten izin } \\
\text { verilmesi }\end{array}$ & İş yerinden izine $(n=1)$ \\
\hline
\end{tabular}




\section{Tartışma}

$\mathrm{Bu}$ çalışma babaların doğum eylemine katılma konusundaki görüș ve gereksinimlerinin belirlemesi amacı ile 20 baba ile niteliksel olarak yapılmıştır. Çalışmada babaların bildirdiği görüşleri ile ilgili beş ve gereksinimleri ile ilgili beş olmak üzere toplam 10 kod oluşturulmuştur. Çalışma kültürel özelliklerimize dayalı olarak babaların intrapartum bakım hizmetlerine dahil olma istekleri ve bu konudaki gereksinimleri ile ilgili önemli ve değerli bilgiler açığa çıkarmıştır.

Çalışmada çoğu babanın doğum sırasında eşlerinin yanında bulunmayı ve eşlerini desteklemeyi istedikleri, fakat bazılarının da fiziksel ve duygusal engeller nedeni ile bunları yapamayacakları görüşünde oldukları belirlenmiştir. Ülkemizde yapılan nicel bir araştırmada da babaların çoğunun (\%72) doğum eyleminde eşlerine destek olma görüşünde oldukları bildirilmiştir [22]. Bu konuda Johansson ve ark. [23]'nın yaptığı meta-sentez çalışmasında da benzer şekilde babaların eşlerinin doğum eylemine aktif olarak katılmayı istedikleri rapor edilmiştir. $\mathrm{Bu}$ çalışmada ayrıca eşlerin, doğumu zorlukları olan ve hazırlık gerektiren bir durum olarak tanımladıkları da bildirilmiştir. Longworth ve ark. [1]'nın yaptığı sistematik derlemede de babaların doğum eylemine katılım düzeylerinin, tanıklık veya pasif bir gözlemciden, aktif destekleyici ve koçluk rolü almasına kadar değişiklik gösterdiği ortaya koyulmuştur. Bir diğer çalışmada da babaların doğum eylemine daha fazla dahil olmak istedikleri, doğum sırasında eşlerini desteklemeye ve bu konuda kendilerinden beklenen rolleri öğrenmeye istekli oldukları belirtilmiștir [24]. Diğer yandan bazı çalışmalarda bu konuda genel olarak babaların ihmal edildiği, bazı engel ile karşılaştığı ve sağlık çalışanları tarafından dinlenmediği ifade edilmektedir [1, 25, 26]. Vallin ve ark. [27]'nın yaptığı sistematik derlemede de babaların, eşlerinin bakımları ile ilgili karar alma sürecine katılamadıklarında, memnuniyetsizlik hissettikleri sonucuna varılmıştır. $\mathrm{Bu}$ sonuçlara göre genel olarak babaların doğum eyleminde eşlerinin yanında olmayı istedikleri ve kendilerine düşen sorumlulukları almaya hazır oldukları söylenebilir. Ancak babaların fiziksel ve duygusal engeller diye tanımladıkları, belki de kültürel olan bazı bireysel durumların da dikkate alınması önemlidir.

Çalışmamızda babaların doğum sırasında eşlerinin yanında bulunabilmeleri ve onlara destek olabilmeleri için bilgilendirilmeye, desteklenmeye, ortamın iyileştirilmesine, yanında olmalarına müsaade edilmesine ve işten izin verilmesine gereksinim duydukları saptanmıştır. Bu konuda yapılan çalışmalarda da benzer şekilde babaların doğum sırasında eşlerine nası destek olacakları konusunda bilgiye gereksinimlerinin olduğu bildirilmiştir [27-29]. Cappelletti ve ark. (30) ise babaların bilgilendirilmeye ilave olarak, sağlık çalışanlarından güvence almaya da gereksinim duyduklarını rapor etmişlerdir. Bir diğer çalışmada da bilgi desteği verilen ve desteklenen babaların daha fazla katılım sağladığı ve olumlu doğum deneyimi yaşadıkları belirtilmiştir [31]. Diğer yandan yeterli bilgi alamamanın da olumsuz doğum deneyiminin yanı sıra belirsizlik, hayal kırıklığı, kafa karışıklığı, öfke, korku ve çaresizlik gibi olumsuz deneyimler yaşanmasına neden olduğu belirtilmektedir [27, 32, 33]. $\mathrm{Bu}$ sonuçlar babaların doğum eylemine katılımlarının sağlanması ve desteklenmesi gerektiğini göstermesi bakımından önemlidir.

\section{1. Çalıșmanın sınırlılıkları}

$\mathrm{Bu}$ çalışmanın bazı sınırlılıkları bulunmaktadır. Bunlardan birincisi, araştırma verileri hastane ortamında, bebeğinin doğumunu bekleyen ya da bebeği yeni doğan babalardan toplanmıştır. Bu süreç, babaların görüş ve gereksinimleri tam olarak tanımlamalarını olumsuz etkilemiş olabilir. İkincisi, birinci araştırmacının araştırma deneyiminin olmaması idi. $\mathrm{Bu}$ durum araștırmanın veri toplama sürecini olumsuz etkilemiş olabilir. Ancak bu süreç ikinci araştırmacının denetimi ve pilot çalışma eğitimi ile kontrol altına alınmaya çalışılmıştır. Üçüncüsü, bu konuda yapılmış herhangi bir ulusal nitel çalışmaya rastlanmamıştır. $\mathrm{Bu}$ durum çalışmanın dış geçerliğinin uluslararası çalışmalara dayalı olarak yapılmasına neden olmuştur.

\section{Sonuc}

$\mathrm{Bu}$ çalışmada, babaların doğum sırasında eşlerinin yanında bulunmayı ve destek olmayı istedikleri, ancak bazı babaların fiziksel ve duygusal engeller nedeni ile bunu yapamayacakları görüşünde oldukları sonucuna varılmıştır. Yine çalışmada babaların doğum sırasında eşlerinin yanında bulunabilme ve destek olabilme ile ilgili bilgiye ve desteğe, eşinin yanında olmaya ve ortamın iyileştirilmesine gereksinimlerinin bulunduğu saptanmıştır.

$\mathrm{Bu}$ sonuçlara dayalı olarak sağlık çalışanları ve yöneticilerinin Anne Dostu Hastane Uygulamaları, gebe eğitim sınıfları ve klinik uygulamalar ile ilgili çalışmalarını babaların da doğuma katılmasını sağlayacak ve babaların görüş ve gereksinimlerini dikkate alacak biçimde düzenlemeleri önerilebilir. Yine örgün ve yaygın sağlık eğitimcilerinin, konuya ilişkin eğitimlerine, babaların intrapartum bakıma katılma konusundaki istek, görüş ve deneyimlerini dâhil etmeleri ve bu uygulamanın yaygınlaşmasına katkı sağlamaları gerekmektedir. Ayrıca farklı örneklem grupları ile benzer çalışmalar yapılarak farklı kültürel özelliklerimizi yansıtan ulusal bilgi birikimine katkı sağlanabilir.

\section{Teșekkür}

Çalışmamızın yürütülmesine izin ve olurları ile destek olan Aydın İl Sağlığı Müdürlüğü ve Aydın Kadın Doğum ve Çocuk Hastalıkları Hastanesi çalışanlarına teşekkür ederiz. Ayrıca çalışmamıza katılan ve çok değerli 
görüşlerini bizimle paylaşan babalara da sonsuz teşekkürlerimizi sunarız.

\section{Mali destek}

Araştırmanın giderleri araştırmacılar tarafından karşılanmıştır. Araştırmamızda herhangi bir çıkar çatışması bulunmamaktadır.

\section{Referanslar}

1.Longworth, MK, Furber, C, A narrative review of fathers' involvement during labour and birth and their influence on decision making, Midwifery, 2015, 31(9), 844-857.

2.Poh, HL, Koh, SSL, Seow, HCL, He, H-G, First-time fathers' experiences and needs during pregnancy and childbirth: A descriptive qualitative study, Midwifery, 2014, 30(6), 779-787.

3. Kuzucu, Y, Değișen babalık rolü ve çocuk gelișimine etkisi, Türk Psikolojik Danıșma ve Rehberlik Dergisi, 2011, 4 (35), 79-91

4. Kara, M, Çetinkaya, Ş, Türk toplumunda babalık kavramı ve bababebek bağlanmasında hemșirelik, Türkiye Klinikleri Hemşirelik Bilimleri, 2019, 11(2), 200-210.

5. Draper, H, Ives, J, Men's involvement in antenatal care and labour: Rethinking a medical model, Midwifery, 2013, 29(7), 723-729.

6. Sapkota, S, Kobayashi, T, Takase, M. Husbands' experiences of supporting their wives during childbirth in Nepal, Midwifery, 2012 28(1), 45-51.

7. Murphy, C, Should dads be in the delivery room? BBC News, Yayın tarihi:25.11.2009, Erissim Yeri: http://news.bbc.co.uk/2/hi/8377099.stm, Erişim tarihi: 05.09.2017.

8. National Responsible Fatherhood Clearinghouse, Responsible fatherhood spotlight: Fathers' prenatal involvement, 2010, Erişim Yeri: https://peerta.acf. hhs.gov/uploadedFiles/prenatal\%20fatherhood.pdf, Erişim tarihi: 10.09.2017.

9. Darwin, Z, Galdas, P, Hinchliff, S, Littlewood, E, McMillan, D McGowan, L, Gilbody, S, and on behalf of the Born and Bred in Yorkshire (BaBY) team, Fathers' views and experiences of their own mental health during pregnancy and the first postnatal year: A qualitative interview study of men participating in the UK Born and Bred in Yorkshire (BaBY) cohort, BMC Pregnancy and Childbirth 2017, 17(1), 45.

10. Howarth, AM, Scott, KM, Swain, NR, First-time fathers' perception of their childbirth experiences, Journal of Health Psychology 2019 24(7), 929-940

11. Maken, ZH, Idrees, IN, Zahid, A, Zulfiqar, A, Munib, A, Hassan, F, Mahmood, R, Factors influencing father's antenatal and perinata involvement in maternal health care, The Journal of Maternal-Fetal \& Neonatal Medicine, 2018, 31(19), 2569-2575.

12. Gungor, I, Beji, NK, Effects of fathers'attendance to labor and delivery on the experience of childbirth in Turkey, Western Journal of Nursing Research, 2007, 29(2), 213-231.

13. Timur, S, Hotun-Şahin, N, Kadınların doğumda sosyal destek tercihleri ve deneyimleri, Hemşirelikte Araştırma Geliştirme Dergisi , 2010, 12(1), 29-40.

14. Royal College of Midwives, Reaching Out: Involving Fathers in Maternity Care, Yayın tarihi: 24.12.2015, Erişim yeri: https://familyincluded.com/family-inclusive-guidelines-maternity/, Erișim tarihi: 10.09.2017.

15. International Confederation Midwives, Essential Competencies for Midwifery Practice, Erișim yeri https://www.internationalmidwives.org/assets/files/generalfiles/2019/10/icm-competencies-en-print-october-2019_final_18oct-5db05248843e8.pdf. Erisim tarihi: 11/12/2019.

16. Fenwick, J, Bayes, S, Johnson, M, A qualitative investigation into the pregnancy experiences and childbirth expectations of Australian fathers-to-be, Sex Reproduction Healthcare, 2012, 3(1), 3-9.

17. Glover, V, Capron, L, Prenatal parenting, Current Opinion in Psychology, 2017, 15(1), 66-70.

18. Güler, A, Halıcıoğlu, MB, Taşğın, S, Sosyal Bilimlerde Nite Araștırma Yöntemleri, 2013, Anmat Matbaacılık San. Ltd. Ști, Ankara, 233-256.

19. T.C. Aydın İl Sağlık Müdürlüğü. Doğum İstatistikleri 2017, Erişim yeri: https://aydinkdch.saglik.gov.tr/TR,132323/dogumistatistikleri-2017.html , Erişim tarihi: 13.12.2019.
20. Aksayan, S, Emiroğlu, N, Araștırmanın Tasarımı, In: Erefe İ Ed: Hemşirelikte Araştırma: İlke Süreç ve Yöntemleri,1.Baskı, İstanbul: Güneș Tıp Kitabevi, 2002: 65-124.

21. Bütün, M, Demir, SB, Nitel Araştırma Yöntemleri, Siyasal Kitabevi, Ankara, 2016, 343.

22. Duru, YTC, Anne ve Babaların Doğum Eylemindeki Eș Desteğine İlişkin Görüşleri, İnönü Üniversitesi Sağlık Bilimleri Enstitüsü Hemşirelik Anabilim Dalı, yayınlanmamış Yüksek Lisans Tezi, Malatya, 2014

23. Johansson, M, Fenwick, J, Premberg, A, A meta-synthesis of fathers experiences of their partner' s labour and the birth of their baby, Midwifery, 2015, 31(1), 9-18.

24. Kaye, DK, Kakaire, O, Nakimuli, A, Osinde, MO, Mbalinda, SN, Kakande, N, Male involvement during pregnancy and childbirth: men's perceptions, practices and experiences during the care for women who developed childbirth complications in Mulago Hospital, Uganda, BMC Pregnancy Childbirth, 2014, 14(1), 54.

25. Mbalinda, SN, Nakimuli, A, Nakubulwa, S, Kakaire, O, Osinde MO, Kakande, N, Kaye, DK, Male partners' perceptions of maternal near miss obstetric morbidity experienced by their spouses, Reproductive Health, 2015, 12(1), 23.

26. Hinton, L, Locock, L, Knight, M, Partner experiences of "near-miss" events in pregnancy and childbirth in the UK: a qualitative study, PloS One, 2014, 9(4), e91735.

27. Vallin, E, Nestander, H, Wells, MB, A literature review and metaethnography of fathers' psychological health and received social support during unpredictable complicated childbirths, Midwifery 2019, 68, 48-55.

28. Wells, MB, Literature review shows that fathers are still not receiving the support they want and need from Swedish child health professionals, Acta Paediatrica, 2016, 105(9), 1014-1023.

29. Eggermont, K, Beeckman, D, Van Hecke, A, Delbaere, I, Verhaeghe, S. Needs of fathers during labour and childbirth: A cross-sectiona study, Women Birth, 2017, 30(4), e188-e197.

30. Cappelletti, G, Nespoli, A, Fumagalli, S, Borrelli, SE, First-time mothers' experiences of early labour in Italian maternity care services, Midwifery, 2016, 34, 198-204.

31. Hildingsson, I, Cederlöf, L, Widén, S, Fathers' birth experience in relation to midwifery care, Women Birth, 2011, 24(3), 129-136.

32. Etheridge, J, Slade, P, "Nothing's actually happened to me.": the experiences of fathers who found childbirth traumatic, $B M C$ Pregnancy Childbirth,2017, 17(1), 80.

33. Zwedberg, S, Bjerkan, H, Asplund, E, Ekéus, C, Hjelmstedt, A, Fathers' experiences of a vacuum extraction delivery: A qualitative study, Sexual and reproductive healthcare, 2015, 6(3), 164-168.

http://edergi.cbu.edu.tr/ojs/index.php/cbusbed isimli yazarın CBUSBED başlıklı eseri bu Creative Commons Alıntı-Gayriticari4.0 Uluslararası Lisansı ile lisanslanmıştır.

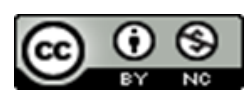

